\title{
Informal Activities in Design Education: Example of Karadeniz Technical University
}

\author{
Selver $\operatorname{Koc}^{1 *}$, Ilkay Masat Ozdemir ${ }^{1}$
}

${ }^{1}$ Karadeniz Technical University, Department of Interior Architecture, Trabzon, TURKEY

*Corresponding Author: selverkoc@ktu.edu.tr

Citation: Koc, S., \& Ozdemir, I. M. (2017). Informal Activities in Design Education: Example of Karadeniz Technical University. Mediterranean Journal of Social \& Behavioral Research, 1(2-3), 63-71. https://doi.org/10.30935/mjosbr/8310

\begin{abstract}
Occupational disciplines (Architecture, Interior Architecture, City and Regional Planning) with design skills with creative thinking make our everyday life more comfortable. These departments, which are of universality quality, have different education disciplines. Informal activities which have a unique place in this discipline; workshops, studio works, symposiums, exhibitions; are carried out using many different methods. Thanks to these studies, students are able to express themselves clearly, to reveal their personality more easily, and to learn how to make vague and variable design decisions through informal activities. In addition, such studies can provide confidence that is important for the profession. Within the scope of the study, the contribution of the informal activities made during the last five years in the department of architecture faculty of Karadeniz Technical University to the students in the design and creation process will be examined. The examinations will focus on what is aimed at the informal activities applied in design education, how they are applied and how they interpret the results.
\end{abstract}

Keywords: design, education, informal activity, workshops

Received: 27 Sep. 2017 Accepted: 9 Nov. 2017

\section{INTRODUCTION}

Education plays an important role in the development of society at the same time in all areas of our life. Different methods of education among disciplines provide students with different forms of development in the professions established on design. Cetinkaya (2011); He pointed out that design is in all areas of life and emphasized that he has been involved in education since the 17 th century and thus has reached academic structure as much as it is day-to-day (Cetinkaya, 2011). One of these educational processes is architectural education.

Architectural design education has a deep and coherent knowledge in design. The information that emerges and is shared when it is designed through design contributes to architectural education (Yuncu, 2008). In the 17th century the architectural design education which started at the Royal Academy of France was considered both art and science, and it was done in order to simplify the architecture (Ertek, 1994). Then in the same century, the French Academy was institutionalized as the Academic Des Beaux-Arts, and in 1819 it continued with the name Ecole Des Beauzé- Arts. The design lessons in the workshops have given architectural perspective. The design lessons realized in the workshops gained architectural perspective (Cetinkaya, 2011). At the same time, contests and conferences were held in this process. The Bauhaus movement, which appeared in the 18th and 19th centuries, provided a great contribution to the education of architecture through the educational program, which was as effective as the day-today (Ozan, 2009). The Bauhaus School has emphasized design lessons to use art and technology together with architectural dill. It has pioneered the concept of design education by gathering different design workshops under one roof (Sahinkaya, 2009). After the Bauhaus, ULM training programs emerged in Germany, intuitively adopting a farreaching analytical approach. In 1960 and beyond, design education focused on the realism of designers, and the use of history by designers was emphasized (Ozalp, 2006). Along with all this process, architectural design education emerges as formal events, which are the basis of design courses in the studio, as informal events which are often short-lived activities that support this process.

Formal education is made up of the theoretical and practical lessons of the designer candidate and can be achieved directly in a fully efficient manner. Formal activities are based on the application of this process (Gurdalli, 2004). In terms of architectural design education, the design and training in the studio provide a great contribution. Because the studios are design areas built on the act of making. At many points, design training is beneficial, while at the same time, some problems are also evident. For example; In studios, the designs originated from the prolongation of the designing process are divided and these divisions lead to disconnection (Uluoglu, 1990). In this point, an alternative thinking was needed in order to complete the design education in an adequate way and with the seminars, workshops, reading and writing exercises and construction actions in the studio, the students were 
sometimes allowed to work individually and sometimes in groups (Ciravoglu, 2001). In this context, the importance of informal activities is huge. Because informal activities are environments that depend on personal experience and authenticity, where there are no limiters in formal activities. Students create ideas and produce products in the context of the subject they want to work with. It; seminars, competitions, reading and writing works, exhibitions, workshops and workshops (Adiguzel, 2012).

Workshops and workships in informal activities are the predominant part of architectural design education. This common point where the production involved in the workshop definition is shared and the ideas are shared offers the possibility of evaluation to the students. Not only workshops and workships, but also all events that do not have compulsory participation, such as symposia, competitions and exhibitions, and which do not have a note system, can also be evaluated as informal activities.

The seminars, competitions, reading and writing activities and exhibitions covered in the informal activities were not evaluated and evaluated through workshops and workshops. Work, workshops and workshops held in the last five years within the scope of the Faculty of Architecture of the Technical University of Karadeniz have been determined and information about their contents has been given.

\section{ARCHITECTURAL DESIGN EDUCATION}

Education has been a phenomenon that has improved itself since the first years of humanity. At the same time, education, with the needs of the people, carries the purpose of research, development and collective service every time (Arcan \& Evci, 1999). Today, it is one of the most important goals of the development of the countries in the name of the progress of the society. The education system in Turkey, which takes place in four stages including pre-primary education, compulsory education, secondary education and higher education, continues in various stages (MEB, 2017).

One of the most important occupational fields in higher education undergraduate programs is 'architecture discipline'. According to Vitruvius (2003) architecture has a different and comprehensive education (Vitruvius, 1993). Because architecture education is both theoretical and design education, students acquire theoretical knowledge as well as their talents and creativity are developing with design education (İnceoglu, 2004). This profession, rooted in ancient times, was first seen in Guild order. Scientific and technological developments that develop with the master-apprentice method have a differentiating phenomenon over time. The French Royal Architecture Academy and Ecole Des Beaux-Arts have subsequently influenced architecture education (Ciravoglu, 2001). Later, Bauhaus and Bauhaus, one of the most important streams for architecture, directed architectural design courses. The Bauhaus school, which has a universal character, became the first basic design education school (Çelik \& Aslan, 2012). Design education within the scope of architecture education is different from other courses because design education is the way to be learned by experiencing directly (Ciravoglu, 2001). Basic design lessons are generally scientific, philosophical, and artistic. This content takes the lesson out of the ordinary, and prepares the student to be a professional man full of creativity (Timucin, 2008). In short, through this tutorial, students learn about basic design and see how a design process emerges, how it develops and how it ends. Therefore, architectural design education is very important for students in the scope of design courses.

Architectural design education is closely related to time, which can lead to thinking and provide the necessary problems during design. At the same time, it strengthens the intuition and common sense of the designers. Students are guided by four basic concepts of thinking / concept development, discussion / criticism, questioning / analysis and evaluation / design. However, open-ended creation in uncertainty creates many different perspectives (Çelik \& Aslan, 2012). This uncertainty and open-ended architectural design education has laid the foundation for the creation of new methods. Therefore, evaluations of how education should be done are still being carried out. According to Ciravoglu (2001); architectural design education is an application that gives a comprehensive experience including formal and informal activities. Studio studies within the context of formal education are generally applied in project courses to improve the skills of students in areas such as drawing, modeling and writing. Informal activities are those involving voluntary participation and evaluation without grading (Ciravoglu, 2001). These include short informal workshops in workshops, formal design education (Yurekli \& Yurekli, 2004).

At this point, informal activities are a big the importance in architectural design education. Because, as long as there are events, students are always more likely to learn by experiencing without a note system.

\section{INFORMAL ACTIVITY}

In design education where formal education is effective, informal activities are a complementary role to formal events. Adiguzel (2012) informal activities; where students can move away from limitations, act on their own initiative, develop design, ideas and products. At the same time, informal education areas are also very important for the students to follow the professional agenda (Adiguzel, 2012). According to Yurekli and Yurekli (2004, p. 54), informal environments are "environments that people behave according to their intuitions, they reveal their personalities more easily, and allow children with a common idiom". From here it is seen that informal events are the biggest means of generating new ideas and products. In addition to this, the students who participate with their own will also reach their final results. It is seen that there are symposiums, competitions, student organizations, exhibitions, seminars, conferences, workshops and workshops that are included in the informal events where original ideas are included, the result of which is the product and the participation is optional. Dinc (2010) points out that the competition, which is a platform that dominates different issues in a short time and has a high risk of losing by producing probing solutions, has a high profitability in the process. Apart from this, student organizations, seminars and conferences provide the opportunity to get up-to-date news and contacts on the professional level. Ciravoglu (2003); WorkShoppers stated that they constitute the weight of informal education (Ciravoglu, 2003). "The difference between the workshops and other organizations (conferences, seminars, exhibitions, performances) is that they are producing in an environment of mutual interaction where they come together for a certain purpose whatever the audience is talking about" (Ciravoglu, 2001, p. 50). For this reason, the study is addressed through workshops in informal activities. 
Table 1. Workshops and departments introduced in the scope of the research

\begin{tabular}{|c|c|c|c|}
\hline Workshops & Year & Architecture & Interior Architecture City and Region Planning \\
\hline Karaköy Workshop & 2013 & $\mathrm{X}$ & \\
\hline Fill In The Blanks & 2015 & $\mathrm{X}$ & \\
\hline Pedestrian Tracks in City Centers & 2015 & $\mathrm{X}$ & $\mathrm{X}$ \\
\hline We have the word & 2016 & $\mathrm{X}$ & \\
\hline Monastery of the Girls & 2016 & $\mathrm{X}$ & \\
\hline Transition & 2016 & $\mathrm{X}$ & \\
\hline Doorstep & 2017 & $\mathrm{X}$ & \\
\hline Konya- Sille Physical Renovation & 2013 & & $\mathrm{X}$ \\
\hline Architecture Styles in interior & 2015 & & $\mathrm{X}$ \\
\hline Edible Furniture Styles & 2015 & & $\mathrm{X}$ \\
\hline Fashion- Place & 2015 & & $\mathrm{X}$ \\
\hline Interdisciplinary Workshop: Surface, Form, Texture & 2016 & & $\mathrm{X}$ \\
\hline Soil & 2017 & & $X$ \\
\hline Designing of urban furniture in traditional texture in Konya Sille in a method & 2017 & & $\mathrm{X}$ \\
\hline Edible Kitchen Styles & 2017 & & $\mathrm{X}$ \\
\hline Inner Castle at the Inner Castle Trabzon and Time & 2017 & & $\mathrm{X}$ \\
\hline
\end{tabular}

\section{WORKSHOPS}

The workshop, which is an English term and is called a workshop study or workshop, also means a seminar conducted outside the university (Tureng, n.d.). Workshops are an important location for all faculty with design training. It is known that not only creativity but also educational direction is also at the same time (Kulaksizoglu, 1995). The length of workshops that can be done on various topics can vary. It seems that the problems that can not be solved in the studio works or the difficulties in the long-spread design are solved by the idea exchange and friends in the informal environment inherent in the workshop. It is possible to mention positive effects such as support for group work, strengthening of interdisciplinary communication, formation of selfconfidence that can be achieved in free environments, acquisition of different perspectives, experience with products that are emerging in a short time (Ciravoglu, 2001).

In workshops where flexibility is important, the executives should be able to exist both effectively and not to feel their presence. In this way, they catch the intelligence of the environment with the brain storm, revealing the intuitive (Yurekli \& Yurekli, 2004).

When all these are evaluated, The workshops in the last five years, which were held in the Faculty of Architecture of the Technical University of Karadeniz, will be determined and put into practice.

\section{FINDINGS}

Influenced Activities in the Science of Art Faculty of Architecture

Architecture, Interior Architecture and City and Regional Planning departments are included in KTU Architecture faculty. Therefore, the workshops will be examined in three sections in the faculty. The workshops conducted during the last five years of the three sections of Table 1 are given. Among these, some workshops involve collaborative work.
Workshops in Interior Architecture Department

\section{3-2014 Konya-Sille physical renovation}

Karadeniz Technical University and Selçuk University jointly carried out a workshop study. 'Physical Renewal' project was conducted with 60 students within the scope of Interior Architecture Project 4 at the historic Konya-Sille settlement located on 'Silk Road' and 'Spice Route' between 1-4 March 2013 (Erbay, 2014).

\section{4-2015 'Architecture styles in interior'}

The workshop product festival held within the scope of the interior architecture style selection course was held on June 3, 2015 in the Department of Interior Architecture. In addition to the elective course, the workshop, which was voluntarily contributed by the students, was very popular with the textiles, clothing, footwear and leather department (Erbay, 2015).

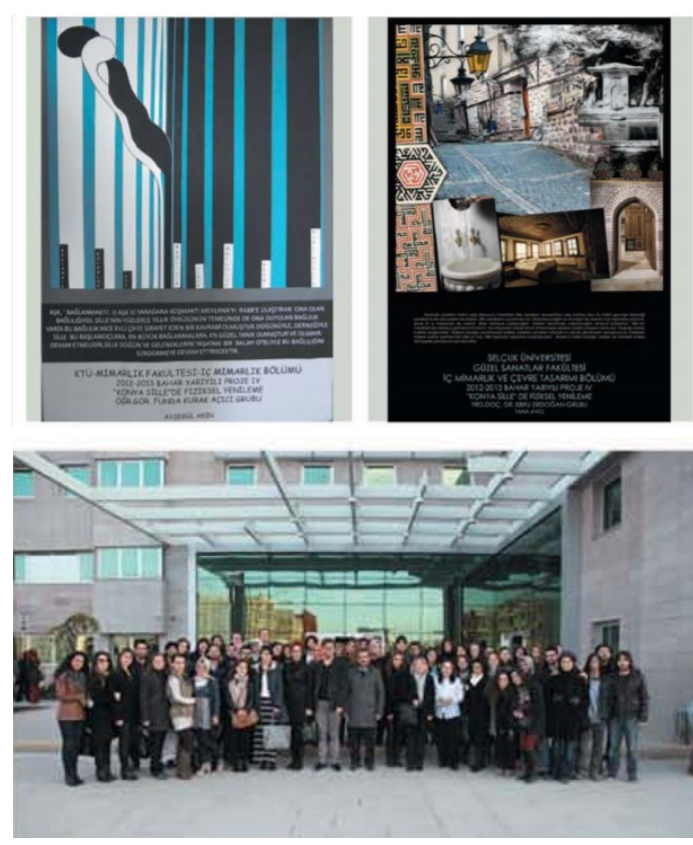

Figure 1. Workshop Photos (Erbay, 2014) 

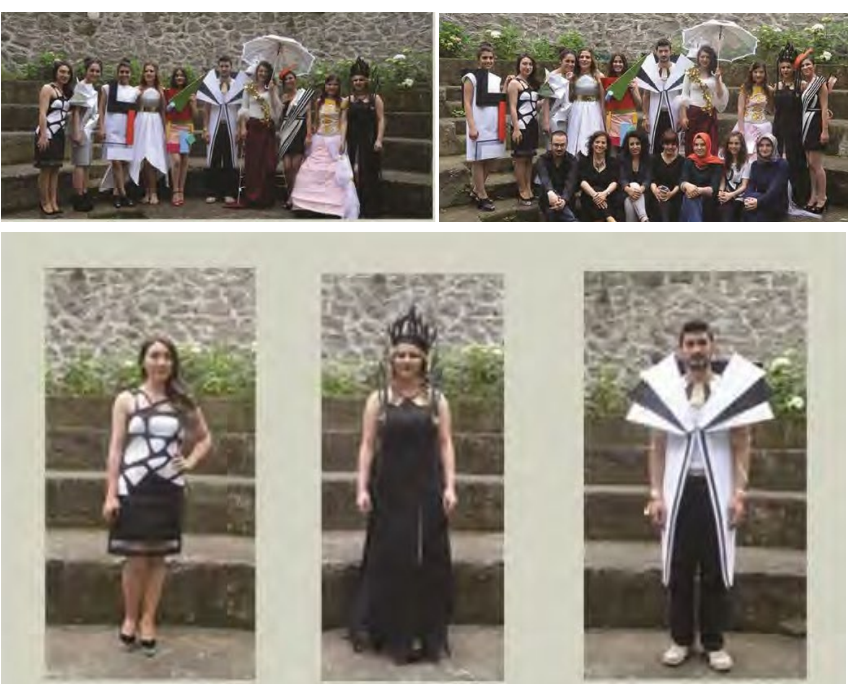

Fütürizm

Gotik

Art Deco

Figure 2. Workshop Photos (Erbay, 2015)
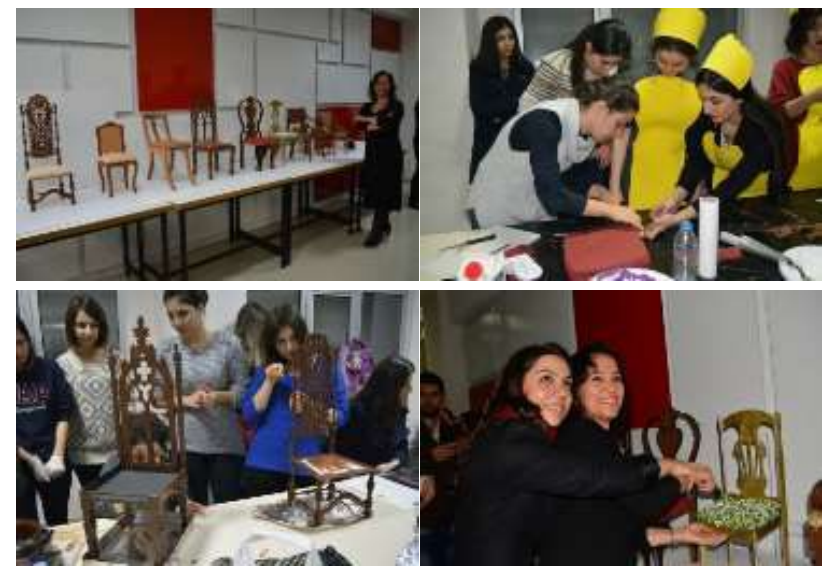

Figure 3. Workshop Photos (Erbay, 2016)

\section{5-2016 'Edible furniture styles'}

2015-2016 Fall Semester On December 04, 2015, "Renewable Furniture Styles" is a workshop study in which the furniture styles from antique furniture to modern furniture are presented with renewable materials are realized within the scope of Furniture History Course of KTU Interior Architecture Department. The resulting products were eagerly defeated after the exhibition (Erbay, 2016).

\section{5-2016 'Fashion-place'}

2015-2016 Fall Semester A workshop was held on 22-25 October 2015 as a joint venture between the Department of Interior Architecture and the Textile, Clothing, Leather and Footwear Departments with the theme of "Moda-Mekan". Inspired by the Interior Styles, clothes were designed and exhibited (Erbay, 2016).
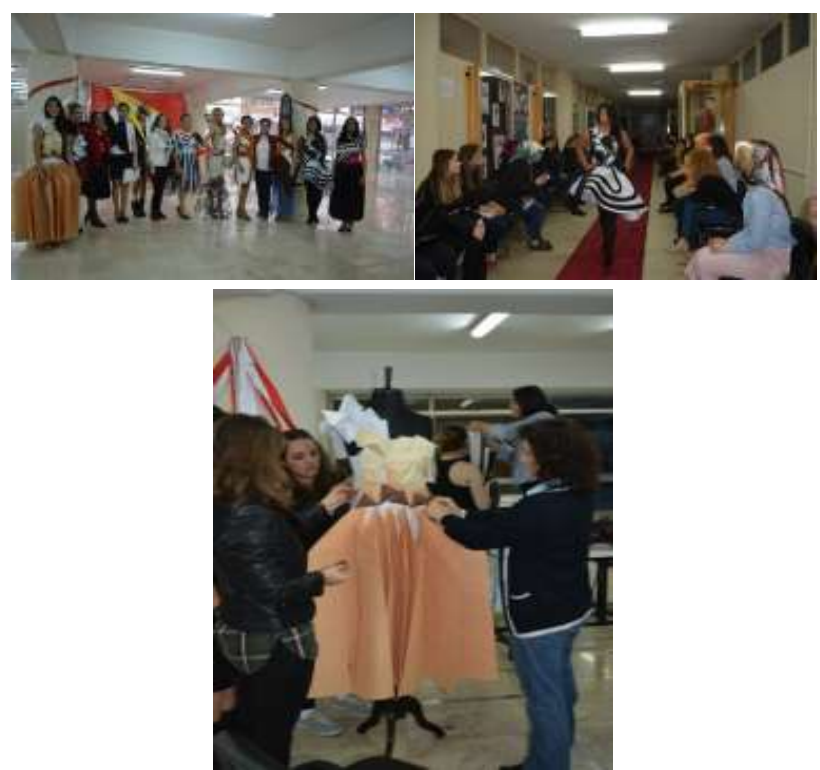

Figure 4. Workshop Photos (Erbay, 2016)

\section{5-2016 Interdisciplinary workshop: Surface, form, texture}

2015-2016 Spring Semester A workshop on "An Interdisciplinary Workshop: Surface, Form, Texture" was held between 28th and 29th of May 2016. 4th building inspiration was made on the result of the trip to Erzurum (Erbay, 2016).

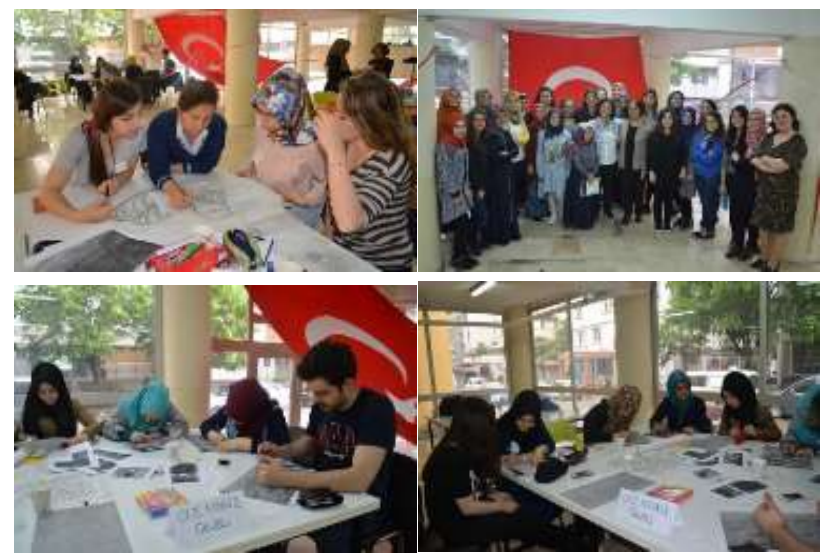

Figure 5. Workshop Photos (Erbay, 2016)

\section{6-2017 'Soil'}

Between 06.03.2017 - 03.03.2017, it was realized in collaboration of Karadeniz Technical University and Istanbul Kultur University. In the event, saying 'how do you get a house but not my land', the ignorant interior design of today's popular housing projects is open to debate. It is aimed to develop new proposals and questions about "interior" in future housing. On the first day of the two-day workshop, discussion and questionnaires and analysis papers were prepared and on the second day, proposal development, exhibition setup and exhibitionattendance document were presented (Erbay, 2017). 


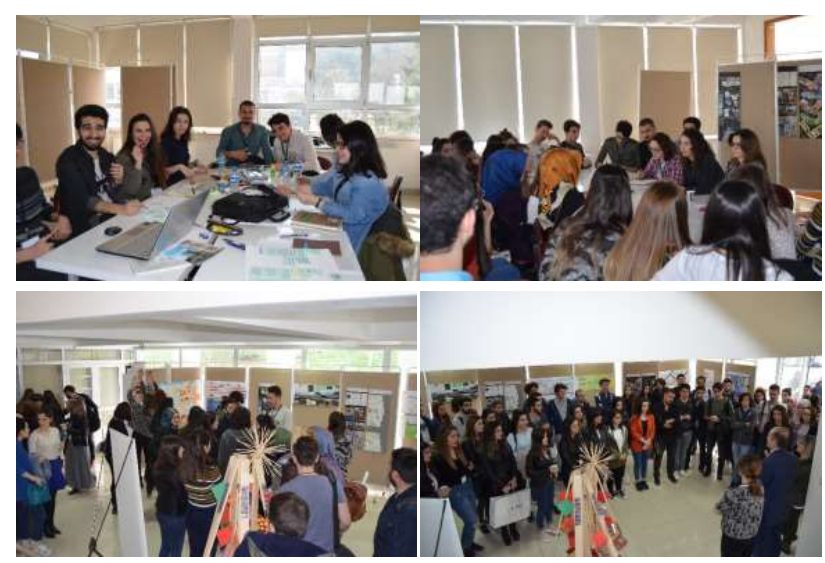

Figure 6. Workshop Photos (Erbay, 2014)

\section{6-2017 Designing of urban furniture in traditional texture in Konya} Sille in a method'

The study was conducted in two stages, 3-4 December and 17-18 December. In the first stage, the participants in the workshop organizing committee were informed about the city furniture and provided students with the first ideas. On the first day of the workshop, ideas were produced and the first concept sketches were formed. A second workshop was held two weeks after the first workshop. On the first day the designs were matured and shaped in the third dimension. On the second day, designs were completed with model studies. All the works prepared within the scope of the study were opened to the public by the designers and the public with the exhibition titled "Konya / Sille", which was told with the "City Furnitures" in the Chamber of Architects of Trabzon between 20-22 February 2017 (Ertas, 2017).
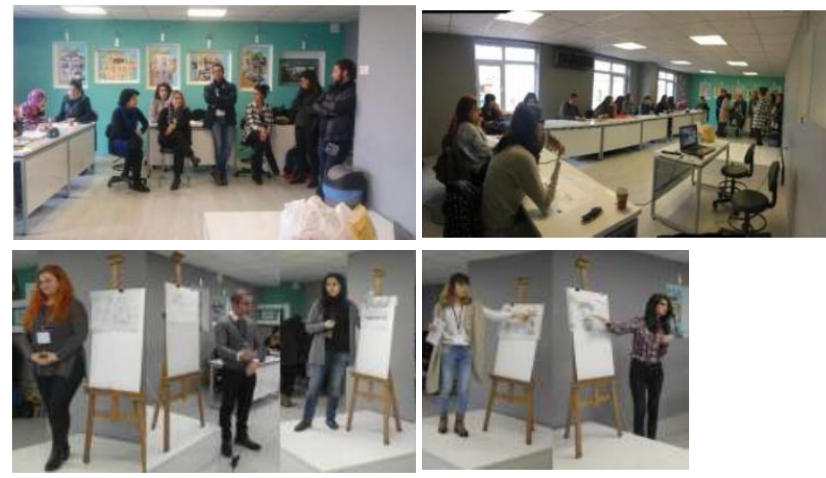

Figure 7. Workshop Photos (Erbay, 2014)

\section{6-2017 'Edible kitchen styles'}

A workshop entitled "Edible Kitchen Styles" was held in Kelebek Kitchen on May 6, 2017 with the participation of students from the Interior Architecture Department of KTU Architecture Faculty. In the first phase, the company started a seminar on the latest trends in kitchen design, produced new surface materials, accessories and a kitchen design application from design to final product. In the second phase, students will learn the kitchen model 'Pierina', one of the latest trends of Kelebek Mutfak, they have implemented a small model of the slogan appropriately in scale. It was made in six sized edible seats with features that reflect the interior style (Erbay, 2017).

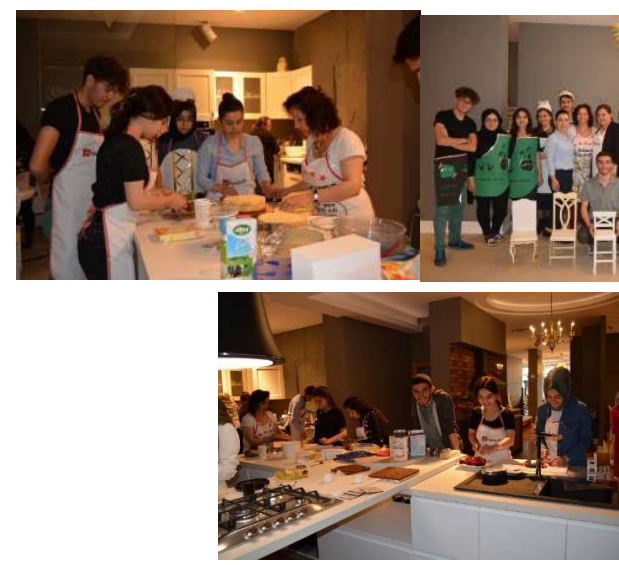

Figure 8. Workshop Photos (Erbay, 2014)

\section{6-2017 'Inner castle at the inner castle Trabzon and time'}

The study entitled "Ic Kalede Icten Ice Trabzon ve Zaman" which was realized in Ortahisar Cultural and Tourism Directorate's former Governorship Building in collaboration with the Interior Architecture Department of the Faculty of Architecture of the KTU Architecture, the Chamber of Interior of the TMMOB and the Provincial Culture and Tourism Directorate participated in the workshop and 55 interior students attended the workshop. Within the scope of the study, the concepts determined from the cultural values of Trabzon city and city were transformed into forms. The final products were exhibited at TMMOB Chamber of Interior Trabzon Branch between 12-19 May 2017 (Figure 9) (Erbay, 2017).

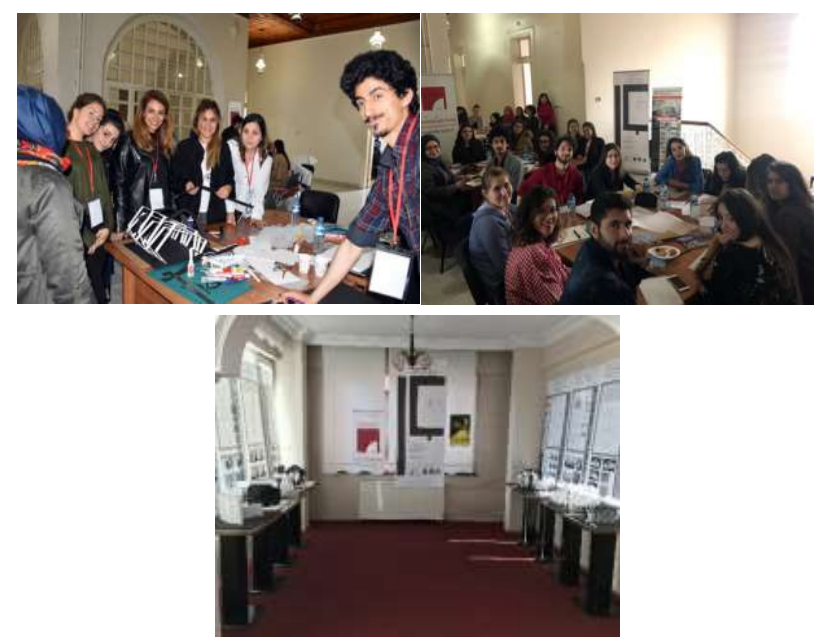

Figure 9. Workshop Photos (Erbay, 2014)

Workshops in the Architecture Department

\section{3-2014 Karakoy workshop}

Karadeniz Technical University, Istanbul New Century University and Beykent University for 7 days. Workshops were held on important issues such as worn out historical textures, dysfunctional areas, insensitivity to the environment, and search for solutions were developed (Oymen Gur et al., 2014). 




Figure 10. Workshop Photos (Oymen Gur et al., 2014)

\section{5-2016 'Pedestrian tracks in city centers'}

With the participation of KTU Architecture, City and Regional Planning and Landscape Architecture, it was aimed to contribute to the city center of Trabzon by producing a solution proposal for the city center. Urban design and planning proposals were presented with the aim of reviving the city centers by considering the 4 day workshops together as tracks (Kuloglu et al., 2016).
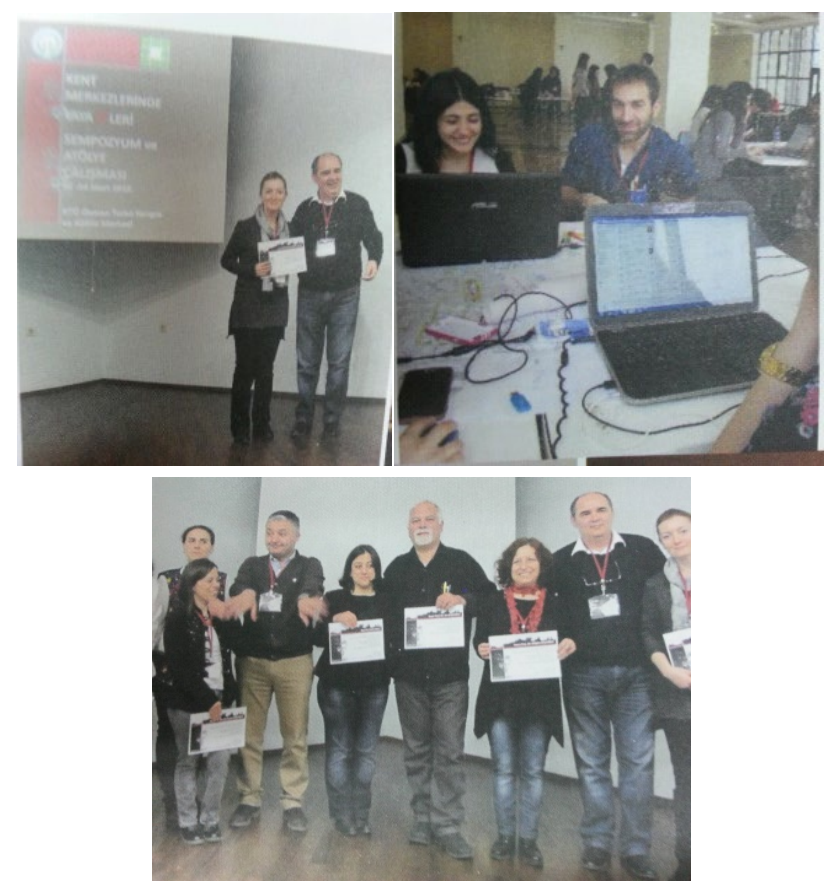

Figure 11. Workshop Photos (Kuloglu et al., 2016)

\section{5-2016 Fill in the blanks'}

The workshop organized by the Architecture Department of the Faculty of Architecture of the Faculty of Architecture of the Faculty of Architecture of the Faculty of Architecture of the Turkish Republic of Northern Cyprus (SEPA) and held in September 2016 includes the historic alanda street work in Fener- Balat. It has been discussed how to fill these gaps in the street and what the design approaches should be. The last day of the workshop, where different approaches were found, ended with presentations (Kuloglu, 2016).
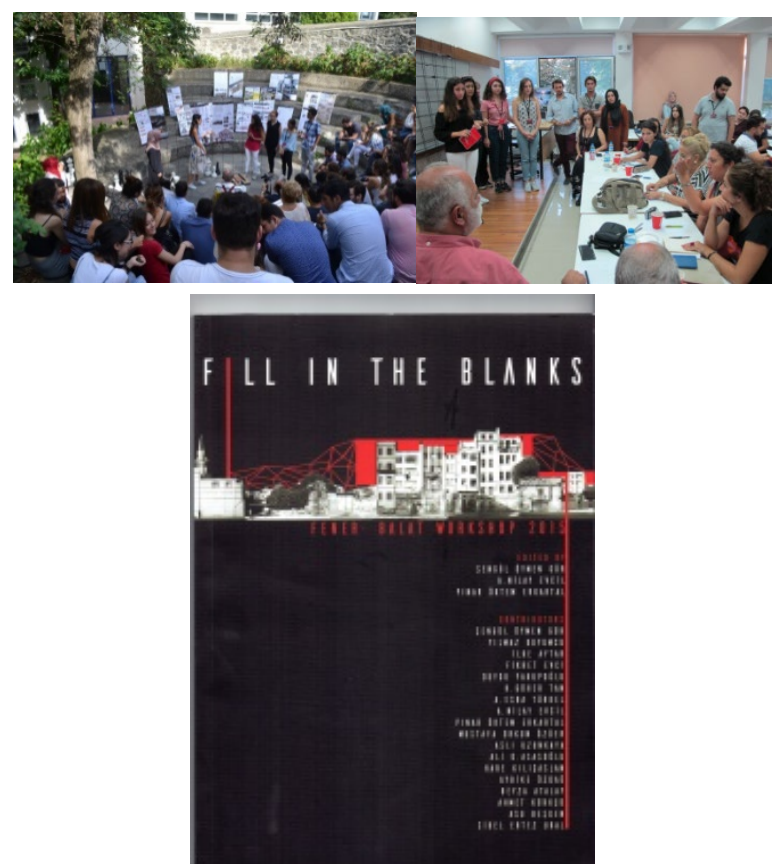

Figure 12. Workshop Photos (Kuloglu et al., 2016)

\section{6-2017 'Love'}

At the workshop held by the Architectural Department of the Faculty of Architecture of the Faculty of Architecture of the Faculty of Architecture of the Republic of Turkey on 28 April - 2 May 2017, love and play were played and questions were raised and ideas were produced. The ideas produced were presented on the last day (Fikir Sanat Tasarim, 2017).

\section{6-2017 'Doorstep'}

The workshop was held internationally between 20-24 April 2016. "Threshold" was discussed with the participation of the students and lecturers of the Universty of Thessaly, Thessaly of Greece, Ss.Cyril and Methodius of Universty of Skopje, and the results of the architectural threshold related product (Karakoç, 2016a).

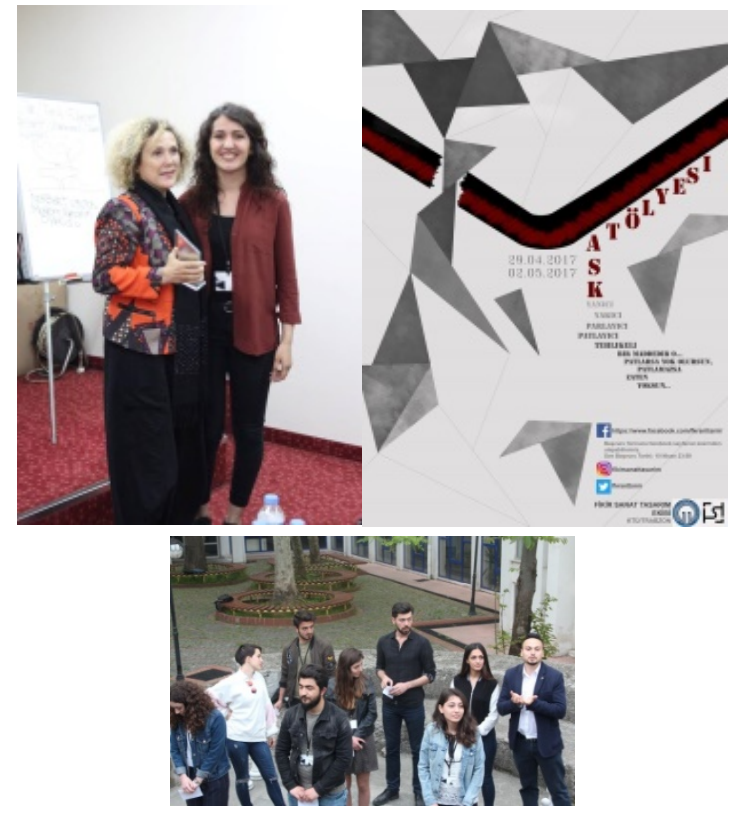

Figure 13. Workshop Photos (Fikir Sanat Tasarım, 2017) 



Figure 14. Workshop Photos (Karakoc, 2016a)

\section{6-2017 'Monastery of the girls'}

The workshop was held on 25-27 March 2016 with the participation of the Faculty of Architecture of the Faculty of Architecture and the Mediterranean, Gaziantep, Pamukkale, Zirve and Canik Basari Universities. The present situation of the girls' monastery was discussed and then the monastic modern approach techniques were proposed (Karakoc, 2016b).
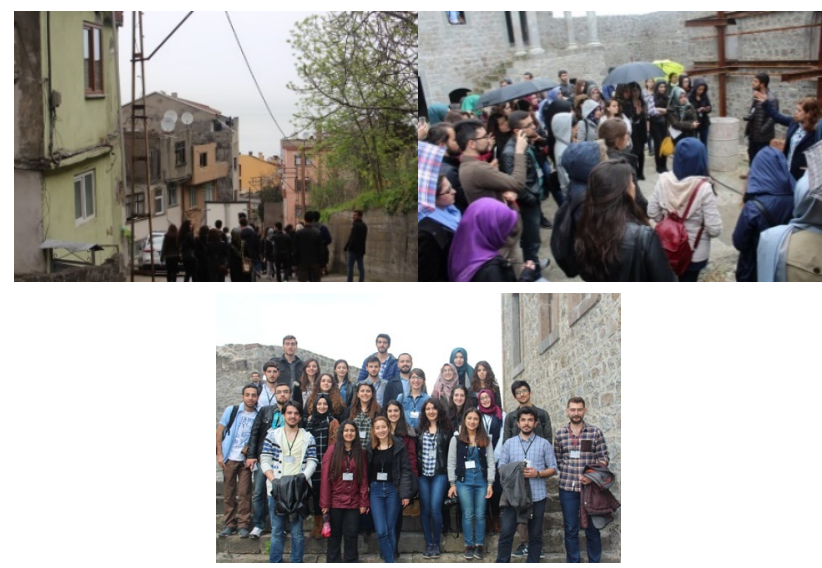

Figure 15. Workshop Photos (Karakoc, 2016b)

\section{6-2017 We have the word'}

The workshop work of S'OZ Bizde, which Mimar Sinan Fine Arts University, Erciyes University and Yildiz Technical University students, which was made by Fikir Art Design Club within the scope of KTU Faculty of Architecture, was held between 16-19 April 2017. Lost and ignorant, the question of what was brought about the $\mathrm{Oz}$ was questioned, awareness was formed. Problems were identified and new products were introduced (Sudas, 2015).

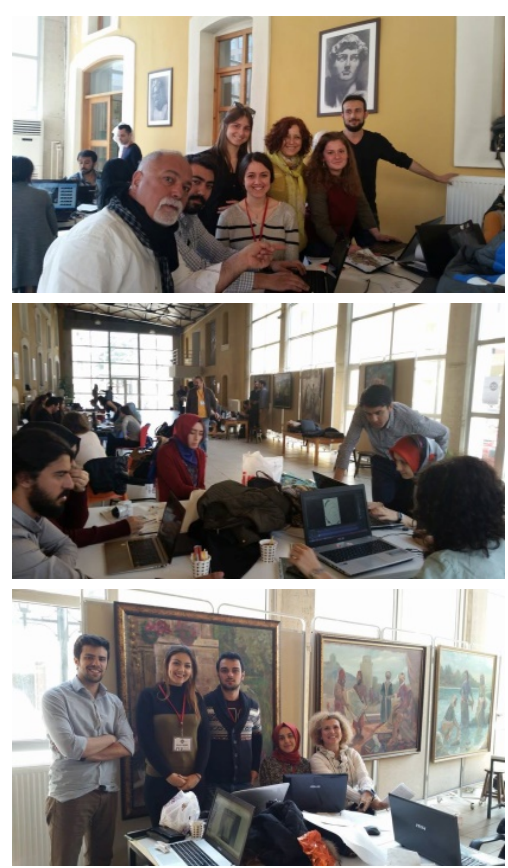

Figure 16. Workshop Photos (Sudas, 2015)

\section{6-2017 Transition'}

The workshop "Transition", which is the pioneer of KTU Architecture Department, was held on 3-10 September 2016. Within the scope of preserving, improving and / or renewing the function of the "Women's Market" region, it was aimed to introduce conceptual solution proposals that are triple culture-identity-context in urban and local problems.

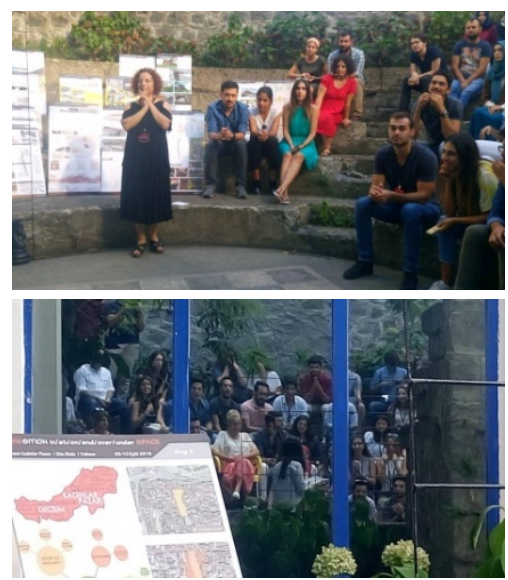

Figure 17. Workshop Photos (from Dr. Asu Besgen’s archive)

\section{Workshops in City and Regional Planning Department} 2015-2016 'Pedestrian tracks in city centers'

With the participation of KTU Architecture, City and Regional Planning and Landscape Architecture, it was aimed to contribute to the city center of Trabzon by producing a solution proposal for the city center. Urban design and planning proposals were presented with the aim of reviving the city centers by considering the 4-day workshops together as tracks (Kuloglu et al., 2016). 




Figure 18. Workshop Photos (Kuloglu et al., 2016)

\section{CONCLUSION AND RECOMMENDATIONS}

Through the communication that informal events have brought to the students within the faculty of architecture, where design education is important, students have been able to present ideas and products in free working environments. Thanks to the flexibility of operation, different disciplines have come together and have been able to work together.

This study encompasses the faculty of architecture, where design education predominates, and includes the last five years of workshops identified as the most important informal activities. 8 workshops were identified in the Department of Architecture and 9 workshops in the Department of Interior Architecture. The workshop work 'Pedestrian Tracks in City Centers' in the Department of Architecture has been a joint work with the Department of City and Regional Planning. Apart from this, no workshops were held in the last five years in the Department of City and Regional Planning. These findings are thought to be the first step for future work. At the same time, the workshops have been another for the purpose of bringing awareness. The workshops under informal activities at the Faculty of Architecture have been able to examine the positive aspects of studio activities and designoriented lectures, which are considered formal events.

\section{REFERENCES}

Adıguzel, D. (2012). Mimarlğın Enformel Eğitim Alam Olarak Çevresel Yaklaşım Konulu Yanş̧malar: Ekopavyon Proje Yanş̧ması Örneği [Competitions on Environmental Approach as an Informal Education Area of Architecture: Example of Ekopavyon Project Competition]. GreenAge Symposium, Mimar Sinan Fine Arts University, Faculty of Architecture, 26-27April 2012, Istanbul, Turkey.

Arcan, E., \& Evci, F. (1999). Mimari Tasanma Yaklaşım 1 Bina Bilgisi Çalş̧malan [Approach to Architectural Design 1 Building Information Studies]. Istanbul, Turkey: Tasarım Publishing Group.
Celik, M., \& Aslan, S. (2012, 20 December). Mekan Tasanm Eğitiminde Temel Tasanm Eğitimi Dersi Ve Dersin İzlenebilirliğine Yönelik Bir Yaklaşım [Basic Design Education Course in Space Design Education and an Approach to the Traceability of the Course], 2nd National Congress of Interior Architecture Education, Istanbul, Turkey.

Cetinkaya, C. (2011). Tasanm Ve Kavram İlişkisinin İ Mimarhk Temel Tasanm Eğitimi Kapsamndaki Yeri: Farkh İki Üniversite Örneği Üzerinden Temel Tasanm Eğitimi Üzerine Bir Araştrma (Masters Thesis), Hacettepe University, Social Sciences Institute, Ankara, Turkey.

Ciravoglu, A. (2001). Mimari Tasanm Eğitiminde Workshop- Stüdyo Paralleliği Üzerine [On Workshop- Studio Parallels in Architectural Design Education] (Masters Thesis), Istanbul Teknik Universitesi, Institute of Science, Istanbul, Turkey.

Ciravoglu, A. (2003). Mimari tasarım eğitiminde formel ve enformel çalışmalar üzerine [On formal and informal studies in architectural design education]. Yapr Dergisi, 257, 43-47.

Dinc, P. (2010). Mimarlı̆ga Yarışanlar: Mimari Yarışmalara Katılımda Süreklilik. Mimarhk, 354, 23-26.

Erbay, M. (ed.) (2014). 2013-2014 Ktü İ́c Mimarhk Bölüm Bülteni [2013-2014 Ktü Interior Architecture Department Bulletin]. Retrieved from http://www.ktu.edu.tr/dosyalar/icmimarlik_9e623.pdf

Erbay, M. (ed.) (2015). 2014-2015 Ktü İ̧ Mimarlk Bölüm Bülteni [20142015 Ktü Interior Architecture Department Bulletin]. Retrieved from http://www.ktu.edu.tr/dosyalar/icmimarlik_dc587.pdf

Erbay, M. (ed.) (2016). 2015-2016 Ktü İ̧̧ Mimarhk Bölüm Bülteni [2015-2016 Ktü Interior Architecture Department Bulletin]. Retrieved from http://www.ktu.edu.tr/dosyalar/icmimarlik_a46e6.pdf

Erbay, M. (ed.) (2017). 2016-2017 Ktü İ̧ Mimarhk Bölüm Bülteni [2016-2017 Ktü Interior Architecture Department Bulletin]. Retrieved from http://www.ktu.edu.tr/dosyalar/icmimarlik_cdd97.pdf

Ertas, S. (2017). Tarihi Çevre İçinde Kent Mobilyaları Tasarımına Yönelik Bir Yöntem Önerisi: Konya Sille. Mehmet Akif Ersoy Üniversitesi Fen Bilimleri Enstitüsü Dergisi, 8(1), 78-95.

Ertek, H. (1994). İç Mekân Temel Tasarm İlkelerine Bir Yaklaşım [An Approach to Interior Basic Design Principles] (Masters Thesis). Hacettepe University, Social Sciences Institute, Ankara, Turkey.

Fikir Sanat Tasarım (2017). KTÜ Fikir Sanat Tasarım Haftası 2017 Ulusal 'AŞK' Atölyesi. Arkitera. Retrieved from http://www.arkitera.com/etkinlik/4225/ktu-fikir-sanat-tasarimhaftasi-2017---ulusal-ask-atolyesi

Gurdalli, H. (2004). Mimann Formasyonunda Formel Mimarlk Eğitiminin Yeri [The Place of Formal Architecture Education in the Formation of the Architect] (Doctoral Thesis), Istanbul Technical University, Institute of Science, Istanbul, Turkey.

Inceoglu, M., \& Inceoglu, N. (2004). Mimarlkta Söylem Kuram ve Uygulama. Istanbul, Turkey: Tasarım Publishing Group.

Karakoc, N. (2016a). Fikir Sanat Tasarım Haftası Etkinlikleri 2 Uluslararası "Eşik" Atölyesi. Arkitera. Retrieved from http://www.arkitera.com/etkinlik/3468/fikir-sanat-tasarimhaftasi-etkinlikleri-2---uluslararasi-esik-atolyesi

Karakoc, N. (2016b). Kızlar Manastırı́na Modern Yaklaşım. Arkitera. Retrieved from https://www.arkitera.com/etkinlik/kizlarmanastirina-modern-yaklasim/ 
Kulaksizoglu, E. (1995). Mimarlğın ve Mimarlk Eğitiminin Evrimi, Mimarlk ve Eğitimi Forum 1: Nasl Bir Gelecek? [Evolution of Architecture and Architectural Education, Architecture and Education Forum 1: What Future?] (pp. 47-51). Taşkışla, İstanbul.

Kuloglu, N., Acar, H., Yavuz, A., \& Gunay, K. (ed.). (2016). Kent Merkezlerinde Yaya İleri Atölyesi. Ankara, Turkey: Aydan Publishing.

MEB (2017, 29 August). Türkiye Eğitim Sistemi [Turkey Education System]. Retrieved from http://www.meb.gov.tr/meb_duyuru index.php?LIST $=\&$ KATEGORI $=\& S A Y F A N O=6$

Oymen Gur, S., Evci, F., Somer, M. E., \& Dur, A. (2014). Karaköy Atölyesi 2013 (1st Ed.), Istanbul, Turkey.

Ozalp, H. (2006). Uluslararast Entegresyon ve Akreditasyon Programlan Kapsamnda Dünya'da ve Türkiye'de İç Mimarlk Eğitimi [Under the Program for International Entegresyo and Accreditation in the world and Interior Design Education in Turkey] (Proficiency in Art Thesis), Hacettepe University, Social Sciences Institute, Ankara, Turkey.

Ozan, M. (2009). Bauhaus Okulu ve Erken Dönem Cumhuriyet Dönemi Mimarisi- Íç Mimarisine Etkileri [Bauhaus School and Early Republican Period Architecture - Effects on Interior Architecture] (Masters Thesis), Yıldız Technical University, Institute of Science, Department of Architecture, Istanbul, Turkey.
Sahinkaya, S. B. (2009). Bauhaus Mobilya Tasarmmnn Günümüz Mobilya Tasanmina Etkileri [Effects of Bauhaus Furniture Design on Today's Furniture Design] (Masters Thesis), Istanbul Technical University, Social Sciences Institute, Istanbul, Turkey.

Sudas, I. (2015). KTÜ Fikir Sanat Tasarım Haftası 2015: Söz Sende. Arkitera. Retrieved from https://www.arkitera.com/etkinlik/ktufikir-sanat-tasarim-haftasi-2015-soz-sende/

Timucin, A. (2008). Eğitim Üzerine Kendimle Konuşmalar - 2 [Talking to Myself on Education]. Istanbul, Turkey : Bulut Publishing.

Tureng (n.d.). Workshop kelime anlam [Meaning of Workshop]. Retrieved on $13 \quad$ September 2017 from http://tureng.com/tr/turkce-ingilizce/workshop

Uluoglu, B. (1990). Mimari Tasanm Eğitimi: Tasanm Bilgisi Bağlamnda Stüdyo Eleștirileri [Architectural Design Education: Studio Criticism in the Context of Design Knowledge] (Doctoral Thesis), Istanbul Technical University, Institute of Science, Istanbul, Turkey.

Vitruvius. (1993). Mimarlk Üzerine On Kitap [Ten Books on Architecture]. Ankara, Turkey: Şevki Vanlı Publications.

Yuncu, O. (2008). Research By Design In Archntectural Design Education (Doctoral Thesis), Graduate School Of Natural And Applied Sciences, Middle East Technical University, Ankara, Turkey.

Yurekli, I., \& Yurekli, H. (2004). Mimari Tasarım Eğitiminde Enformellik [Informality in Architectural Design Education]. İÜ̈ Dergisi/a Mimarlk, Planlama, Tasanm, 3(1), 53-62. 